\title{
Uterine Corpus Adenosarcoma Clinical TNM Finding v8
}

National Cancer Institute

\section{Source}

National Cancer Institute. Uterine Corpus Adenosarcoma Clinical TNM Finding v8. NCI Thesaurus. Code C139843.

A clinical finding about one or more characteristics of uterine corpus adenosarcoma, following the rules of the TNM AJCC v8 classification system. 